\title{
Minding the Care Gap: Daycare Usage and the Negotiation of Work, Family and Gender Among Swedish Parents
}

\author{
Anne Grönlund ${ }^{1}$ (D) $\cdot$ Ida Öun²
}

Accepted: 12 May 2020 / Published online: 20 May 2020

(c) The Author(s) 2020

\begin{abstract}
The article asks whether daycare can alleviate work-family tensions in the dual-earner society or if perceptions of 'care gaps' will hamper women's careers. Using survey data from Swedish parents with pre-school children $(\mathrm{n} \approx 2250)$ and qualitative interviews of survey respondents $(n=40)$, we explore how children's daycare hours and parents' reflections on daycare hours are related to mothers' and fathers' involvement in paid and unpaid work and to their perceptions of stress. The results show that parents have a strong ambition to limit daycare hours. This ambition provides a stressful dilemma for mothers but for fathers, daycare is not a source of stress. Maternal part-time work is an important tool for managing daycare hours, but collides with ideals of gender equality. Full-time work can be combined with short daycare hours, provided that the parents take shifts in the home and share care responsibilities. Sharing of care work also reduces mothers' stress. However, such arrangements require flexible schedules which are more available to parents in highskill jobs. Single parents have little opportunity to keep daycare hours short.
\end{abstract}

Keywords Daycare $\cdot$ Gender $\cdot$ Part-time $\cdot$ Parenthood $\cdot$ Family policy $\cdot$ Flexible schedules

\section{Introduction}

The link between dual-earner family policies and female labour force participation has been firmly established and here, daycare services are assigned with a central role. Beyond the issue of employment, however, the role of daycare has been little explored. A central question is whether daycare can alleviate work-family tensions and allow for two full-time careers or if perceptions of 'care gaps' will call on mothers to limit their work ambitions to avoid a stressful conflict.

With the example of Sweden, the article studies the use and usefulness of daycare at the threshold of the dual-earner society. With a mixed methods approach, combining survey data from employed parents with pre-school children $(\mathrm{n} \approx 2250)$ and qualitative interviews of survey respondents $(n=40)$, we analyze how children's daycare hours and parents'

Anne Grönlund

anne.gronlund@umu.se

1 Department of Social Work, Umeå University, Umeå, Sweden

2 Department of Sociology, Umeå University, Umeå, Sweden 
reflections on daycare hours are related to mothers' and fathers' involvement in paid and unpaid work and to their perceptions of stress.

\section{Previous Research and Our Contribution}

Issues of work-family reconciliation are increasingly focused as European societies struggle to stimulate female labour force participation while simultaneously boosting fertility rates. In this endeavor, daycare services for pre-school children are assigned with a central role and since the early 2000s, the provision of daycare has been strongly promoted by the European Union (European Union 2018).

In the welfare state literature, family policies that promote women's economic independence from a (male) breadwinner are described as de-familializing (e.g. Lister 2003), individualizing (Lohmann and Zagel 2016; cf. Daly 2011) or de-genderizing (Saxonberg 2013). The varying concepts reflect a lack of agreement about definitions and measurements. Nevertheless, scholars seem to agree that publicly financed daycare services for small children are a central element of such policies (Gornick and Meyers 2008; Korpi 2000; Korpi et al. 2013; Lohmann and Zagel 2016; Saxonberg 2013). Empirically, the link between such policies and female labour force participation is well established (e.g., Bettio and Plantenga 2004; Korpi, et al. 2013). However, while female labour force participation has increased across Europe (Eurostat 2019a), persistent gender inequalities in work and family are found even in countries with extensive family policies. Sweden provides a case in point. With long-standing policies promoting a dual-earner family model, Sweden is considered one of the most de-familialized, individualized and de-genderized countries (e.g., Bambra 2007; Lohmann and Zagel 2016; Saxonberg 2013). Swedish women early on gained a strong foothold in the labour market and the country still stands out internationally with high rates of female and maternal labour force participation (Grönlund and Öun 2018; Korpi et al. 2013). In a European perspective, Sweden also boasts high fertility rates (Eurostat 2019b) and was ranked number one on the EU gender equality index 2019 (EIGE 2019).

At the same time, Sweden provides a close-up view of the challenges facing parents at the threshold of the dual-earner society. On the one hand, Swedish women are strongly committed to work and career, as witnessed by their investments in higher education (Björklund et al. 2010) and their increasing work hours (Statistics Sweden 2017). Yet, substantial gender gaps can be found both in labour market outcomes (e.g., Boye et al. 2017) and in the responsibilities for care and housework (Boye 2014). Here, the early years of parenthood seem decisive. Parenthood has a 'traditionalizing' effect on the division of unpaid work (Boye and Evertsson 2014) with long-term implications for wages and careers (Bygren and Gähler 2012; Angelov et al. 2016; Magnusson and Nermo 2017; Boye 2019). The gendered division of care also translates into differences in health. Swedish mothers report significantly more work-family conflict than fathers (e.g., Grönlund and Öun 2010) and pre-school children dramatically increase levels of sickness absence for mothers, but not for fathers (Angelov et al. 2013). 
The negative reports on inequalities and stress appear puzzling, considering the policy support offered to Swedish parents. In recent debates, scholars depict Swedish ${ }^{1}$ family policies as a gender equality paradox, arguing that the institutionalized rights to work interruptions - through parental leave entitlements and rights to part-time work-encourage employers to discriminate against women, particularly in high-skill jobs (e.g., Mandel and Semyonov 2006; Mandel 2012 — but see Korpi et al. 2013; Bygren et al. 2017). However, the mechanisms sustaining or challenging gendered work-family arrangements are not addressed in these debates. The Swedish family policies have set the stage for the modern, 'negotiated' family in which given roles have dissolved, as described in the influential individualization theory (Ahlberg et al. 2008). However, this theory neglects to discuss how deep-seated norms around gender and parenthood will affect families' behaviour (ibid). Thus, neither the welfare state literature nor modern family theory has outlined the process of behavioural change.

Against this background, it seems pertinent to explore how family policy tools are perceived and utilized in parents' work-family arrangements. To some extent, these issues have been addressed in studies of parental leaves (e.g., Grunow and Evertsson 2016). However, parents' deliberation on daycare remains something of a 'black box'.

To unpack that box, we must connect parents' perceptions to the institutional framework of the dual-earner policy model. Here, we propose that policies provide parents with two concurrent messages. The policies foster a strong role expansion logic, which is aspirations and ideals based on the notion that women (and men) could and should aim for dual roles in work and family. In their support for female employment these policies can be described as de-familializing-yet, they also make room for families. On the one hand, parents have access to full-time daycare services for children from age 1. On the other hand, policies strongly support the care for children in the home through generous parental leaves, rights to part-time work and paid leave to care for sick children. ${ }^{2}$ Thus, they provide parents both with a right to work and a right to care.

Clearly, these rights can also be regarded as responsibilities. In particular, mothers are faced with double discourses: one emphasizing employment, independence and career, the other underlining the importance of intensive mothering (Elvin-Nowak 1999; cf. Hays 1998). Increasingly, Swedish fathers also aspire to an active, involved parenthood (Grunow and Evertsson 2016) a large majority subscribe to ideals of equal sharing of paid and unpaid work (Edlund and Öun 2016). However, in comparison to mothers, few fathers use the right to part-time work and, particularly in male-dominated jobs, fathers face problems reducing work hours and using parental leaves (Grönlund and Öun 2018; Bygren and

\footnotetext{
1 While the dual-earner policy model is commonly described as a Scandinavian model, there are also differences in family policies between the countries (see e.g., Grönlund et al. 2017).

2 In Sweden, municipal governments are required to provide full-time daycare for children from age 1. Preschool centers are publicly financed (but may be publicly or privately run) and fees are income-tested with a low legal cost limit (currently Euro 134 for the first child and reduced rates for additional children). Swedish family policies also provide parents with extensive rights to care for children in the home. The current parental leave scheme entails 390 days compensated at $80 \%$ of income plus an additional 90 days at a flat rate. The parental leave scheme is gender-neutral with symmetrical rights for mothers and fathers. 90 days are reserved for the father and 90 days are reserved for the mother, the rest of the leave can be shared between the parents as they wish. Parental leave compensation can be used flexibly to reduce work hours up to $75 \%$ over eight years. Also, parents have a statutory right to reduce work hours by up to $25 \%$ until the child is 8 (with a corresponding reduction in wages). Finally, temporary parental leave scheme enables parents to stay home with a sick child up to 120 days/year until the child is 12 (compensated at $80 \%$ of income).
} 
Duvander 2006). Thus, tensions between work and care, as well as between traditional roles and new ideals, remain salient in the dual-earner policy context.

Daycare services provide a lens for a close-up study of these tensions. In Sweden, public fulltime daycare has been widely available since the 1980s (Grönlund et al. 2017) and coverage rates clearly exceed the EU average, particularly for the youngest children (European Union 2018). However, while enrolling the children in daycare is a normalized, integral part of Swedish parenthood (Grönlund and Kaufman 2019), it is not obvious that daycare can or will be used in a way that allows both parents to engage in full-time careers. Extensive use of daycare may be hampered by post-modernist values emphasizing children's well-being (Hobson et al. 2011) and by parenthood ideals of 'concerted cultivation' which urge parents to spend time (and resources) on developing their children's competencies through e.g. after school activities (Lareau 2003). Thus, parents-particularly mothers-may strive to limit children's hours in daycare.

As a result, deliberations on daycare hours could be a source of stress and a barrier to mothers' full-time work. However, these relationships could be influenced by several factors, in particular the flexibility of work and family roles. Flexible work arrangements, notably flexibility schedules, are extensively discussed as a tool for reconciling work and family (e.g., Pitt-Catsouphes et al., 2006; Byron 2005; Allen et al. 2013; Michel et al. 2011). Presumably, such schedules, as well as a spatial flexibility allowing employees to work from home, could enable parents to limit daycare hours without resorting to part-time work. Obviously, the partner's work hours and the compatibility (or lack of compatibility) between the parents' schedules must also be considered as factors that affect the extent to which parents can 'take shifts' in the home. Finally, a more equal sharing of care work in the family could relieve some of the pressure on mothers to adapt work hours and provide a buffer against daycare-related stress. Below, these propositions will be empirically explored in a mixed-method study of Swedish parents.

\section{Aim and Research Questions}

The analysis is based on a QUANT-qual design where findings from survey data (Part 1) are further explored in qualitative interviews (Part 2). The overall aim is to explore how children's daycare hours and parents' deliberations on daycare hours are related to mothers' and fathers' involvement in paid and unpaid work and to perceptions of stress.

\subsection{Research Questions Part 1 (Quantitative)}

1a. How are longer/shorter daycare hours related to mothers' and fathers' work hours?

1b. Can flexible work arrangements and a more equal sharing of care work in the family allow both parents to work full-time without prolonging daycare hours?

2a. Are daycare hours and ambitions to limit daycare hours related to perceptions of stress?

2b. Is the relationship between daycare hours and mothers' stress modified if care work is shared more equally?

\subsection{Research Questions Part 2 (Qualitative)}

3. How do mothers and fathers talk about limiting daycare hours in terms of motives and strategies? 
4. In what ways are daycare hours and ambitions to limit hours related to stress in the parents' narratives?

\section{Data and Methods}

The study presented here is based on a mixed methods approach. Broadly, this means combining quantitative and qualitative data in a single study (Tashakkori and Teddlie 2003). Mixed methods studies can vary in their objectives and designs and in the notation commonly used to classify them our study would be described as a sequential explanatory QUANT-qual study (Creswell et al. 2003). This means that the data collection started with the quantitative data, which later was complemented by qualitative data. In the analysis, priority was given to the quantitative data while the qualitative data would assist in explaining and interpreting the findings. A major strength of such a design is the possibility to "simultaneously confirm a quantitatively derived hypothesis and explore in greater depth the processes by which the relationship occurred" (Tashakkori and Teddlie 2003:16). Clearly, the approach has some limitations and there is reason to reflect upon how data derived from mixed methods can be integrated (Onwuegbuzie and Teddlie 2003). We will return to these issues in the discussion. In this section, we will describe the two datasets and how each of them was analyzed.

\subsection{Quantitative Data}

The data for the first, quantitative part comes from a postal survey conducted in Sweden during the winter of 2015-2016. Sampling, distribution, and coding was administered by Statistics Sweden. The sample was a simple random sample drawn from the National register of the total population and comprised 5000 parents whose youngest child was between 3 and 6 years of age at the time of the survey. The sampling strategy was motivated by our focus on daycare usage and work-family reconciliation. For this reason, we wanted to include parents whose youngest child had not yet started school but exclude families in which one of the partners could still be on full-time parental leave. It should be noted that although some families may also have older children, all questions refer to the youngest child.

Due to an initial mistake in the sampling procedure at Statistics Sweden, the sample of 5000 parents had to be drawn twice. The first sample erroneously included parents who also had a child who was younger than our target group, and therefore the initial survey was paused at an early stage and a new sample was drawn. The response rate of the second correct sample was 35\%. However, as some respondents from the first sample matched our criteria for inclusion, it was possible to add these respondents to the final sample to increase the statistical power of our analyses. ${ }^{3}$

Analysis of non-response shows little difference in responses between mothers and fathers. Individuals with only compulsory education (and unclassified education) were underrepresented among the respondents, while those with tertiary education were overrepresented. However, the share of individuals with secondary education did not differ

\footnotetext{
${ }^{3}$ Calculations made by Statistics Sweden confirmed that their sampling probability was very similar to that of the second sample.
} 
substantially from that of the population. Also, immigrants and children of immigrants were underrepresented among the respondents, as were individuals with very low incomes. On the basis of this information, we conclude that the analyses presented here are likely to capture the situation for parents with secondary and post-secondary education (together representing $75 \%$ of the population) but may not fully reflect the work-family arrangements of groups that are more marginalized on the labour market. In the quantitative part of this article, we use a subsample comprising employed mothers and fathers $(\mathrm{n} \approx 2250)$.

\subsection{Qualitative Data}

Data for the second, qualitative part of the article comes from 40 interviews with respondents that had previously taken part in the survey described above. Respondents in the survey had the possibility to agree to be contacted for follow-up interviews, and as almost 890 respondents opted in for this alternative (539 women and 348 men), we were able to strategically recruit interview respondents on the basis of gender and educational level. During the recruitment process we also made sure there was variation among the respondents on aspects such as family type (married/cohabiting and single parents) and geographical location (region, urban-rural). The final sample included 20 mothers and 20 fathers. 26 of the respondents had a university degree, the others did not. Also, a number of occupations were represented at each educational level. $25 \%$ of the respondents had one child, $45 \%$ had two children and $30 \%$ had three or more children.

The interviews were conducted via the internet during winter and spring 2018. They lasted on average $60 \mathrm{~min}$ and were audio recorded and transcribed. For the interviews, an interview guide was developed including questions about different statutory policy rights aimed for parents to reconcile dual roles in work and family, i.e. daycare, part-time work, parental leave and leave to care for sick children. The logic was to capture mothers' and fathers' reasoning about the usage and usefulness of these policy entitlements as well as their perceptions of conflict and strategies in relation to combining work and family. Questions were mostly about the respondents' current situation in terms of work and family demands and reflections about the role of policy in connection to this situation, but retrospective questions about parental leaves and working time arrangements were also included as well as questions about parenthood ideals and sharing of responsibilities with the partner.

\subsection{Quantitative and Qualitative Analyses}

The quantitative data was used for two sets of analyses. To answer RQ 1a-b, we first identified family patterns of work hour arrangements and daycare hours using Latent Class Analysis (LCA). Three variables were included in this analysis: Respondents' work hours categorized into part-time ( $<35 \mathrm{~h} /$ week), full-time (35-40 h per week), and more than full time ( $>40 \mathrm{~h} /$ week). The variable partners' work hours was categorized into part time, full time, more than full time, and no partner. Daycare hours were divided into short ( $<$ median, 36.9, hours) and long (>median] hours. Thus, we use parents' reports of daycare hours to explore patterns in work-family arrangements and clearly, the labels 'short' and 'long' do not signify any normative valuation of daycare usage.

The structure of the three variables was explored by using LCA, a method that enabled us to retrieve nonlinear relationships between categorical variables, in order to identify qualitatively different configurations of work hour arrangements and day care hours. 
In LCA, the notion of local independence is central: the method examines whether relationships within a set of observed indicators are explained by latent clusters (Hagenaars and McCutcheon 2002; McCutcheon 1987). LCA distinguishes dominant patterns of work hours and daycare hours in the data, and all respondents sharing similar patterns are allocated to a specific cluster. Thus, the objective of this data-reduction method is to identify groups of individuals who share similar characteristics. For example, if two dominant patterns of work hour arrangements and daycare hours exist among the respondents, a twocluster model will fit the data. If the sample can be divided into three main configurations of work hours and daycare hours, a three-cluster model will be selected, and so on. By applying different model fit statistics, the number of dominant clusters can be determined.

LCA also calculates the probability of each individual to belong to each cluster and in the next step of the analysis, we examine how cluster membership probabilities relate to respondents' work arrangements and family roles. This analysis was based on ordinary least square regressions, OLS, in which the LCA clusters were used as dependent variables. The independent variables included the respondents' gender, education (university/ non-university) and whether they lived together with a partner or not. Three indicators captured flexible work arrangements, namely if the respondent and/or the partner had a flexible work schedule (yes/no), if the respondent and/or the partner had a non-daytime schedule (yes/no) and if the respondent could perform (some of) his/her work from home (never/ sometimes/often). The father's share of childcare responsibilities was measured with an additive index of five common child care chores and describes which of the spouses usually takes care of the chore. The index was based on the following question: In your household, who does the following things...? (a) leaves/picks up children from childcare, (b) drives children to activities, (c) puts children to bed, (d) plans family activities, (e) takes care of sick children (response categories: always the mother; usually the mother; about equal or both together; usually the father; always the father; is done by a third person). The index ranges from 5 to 25 and higher values indicate that the father does a larger share of the child care work (alpha $=0.64$, mean $=13.64)$. Cases where a task is performed by a third person were included in the category of equal sharing. To get a comprehensive view of care work we also included two variables capturing whether the respondents regularly purchase household services (yes/no) and whether they receive help from relatives/friends with housework and childcare (yes/no).

To address RQ 2a-b, we performed OLS regressions with stress as the dependent variable. Stress is an additive index built on three variables capturing the respondent's feelings of stress, anxiety and sleeping problems (scale 3-21, higher values indicate more stress, alpha $=0.78$, mean $=11.02$ ). The main independent variables were the desire to limit daycare hours (yes/no; yes includes respondents who agree/strongly agree that they strive to limit daycare hours) and the actual use of long daycare hours ( $>$ median). Other independent variables in this part of the analysis included education, father's share of childcare responsibilities (both described above) and also job demands and job control, established as central factors in research on work and stress (Karasek and Theorell 1990; van der Doef and Maes 1999). Job demands is an index of two survey questions that measure the time pressure and the mental strain inherent in the respondent's job (range 2-10, higher values indicate higher demands). Job control is an index of four questions capturing the respondent's degree of control over (a) which work tasks to perform, (b) the way to perform work tasks, (c) work pace, and d) important decisions concerning the work place (range 4-20, higher values indicate more control). Regressions are carried out separately for mothers and fathers. 
In the qualitative analysis we addressed RQs 3 and 4. These questions mirror those posed in the quantitative part but deepen our understanding of daycare usage by focusing on parents' deliberations on motives and strategies for limiting daycare hours. The analysis was based on thematic analysis (Braun and Clarke 2013). With this method, the researcher performs an initial coding of the data, then proceeds to identify themes - that is patterns of responses or meaning - in the data. Next, the researcher creates thematic maps, connecting the themes to each other and the research question, and finally, all themes must be scrutinized to make sure they are clearly defined and firmly based on the data. Thematic analysis can be regarded as a "foundational method for qualitative analysis" (Braun and Clarke 2013:78) as it describes a systematic approach that can be used in many types of qualitative analysis (cf. Miles et al. 2014). At the same time, it is a method in its own right and a major advantage is its flexibility. In contrast to many other methods, thematic analysis is not tied to a certain theoretical or epistemological perspective. Instead, Braun and Clarke argue that the researcher should clarify whether the analysis is inductive or driven by a theory/hypothesis and if the respondents' accounts of motives and actions are treated with an essentialist/realist approach or if they are regarded as socially constructed and used to theorize about contexts and structures. With a design using qualitative data to complement and interpret findings from the survey analysis, our approach can be described as theoretical rather than purely inductive and our focus on gender and policy context implies a constructionist approach.

\section{Results: Part 1 (Quant)}

Before embarking on the analysis, we will consider the parents' perceptions of daycare services, as reported in the survey. Table 1 shows that almost all parents believe that the daycare services used for their youngest child fulfil the child's need for care and development. An overwhelming majority also agrees that the daycare center offers opening hours that fit with the parents' work hours and that hours can be changed flexibly. Thus, daycare services are valued positively and no difference can be discerned between mothers and fathers.

Despite the positive valuations, however, a large share of the parents report that they strive to limit the time their child spends in daycare. This ambition is shared by $70 \%$ of the fathers and $82 \%$ of the mothers, a statistically significant gender difference. Clearly many parents, especially mothers, are intent on keeping daycare hours down. Moreover, the reports on time in daycare suggest that these intentions are often put to practice. On

Table 1 Parents' perceptions of daycare services

\begin{tabular}{|c|c|c|c|c|c|c|c|c|}
\hline & \multicolumn{2}{|c|}{$\begin{array}{l}\text { Daycare fulfils } \\
\text { child's need for care } \\
\text { and development }\end{array}$} & \multicolumn{2}{|c|}{$\begin{array}{l}\text { Daycare opening } \\
\text { hours fit with work } \\
\text { hours }\end{array}$} & \multicolumn{2}{|c|}{$\begin{array}{l}\text { Possible to change } \\
\text { daycare hours with } \\
\text { short notice }\end{array}$} & \multicolumn{2}{|c|}{$\begin{array}{l}\text { Striving to limit } \\
\text { daycare hours }\end{array}$} \\
\hline & Mothers & Fathers & Mothers & Fathers & Mothers & Fathers & Mothers & Fathers \\
\hline Strongly disagree & 0.9 & 1.0 & 2.9 & 1.3 & 4.4 & 4.3 & 4.7 & 10.5 \\
\hline Disagree & 4.4 & 4.9 & 4.7 & 3.2 & 6.9 & 9.1 & 13.5 & 19.5 \\
\hline Agree & 43.1 & 43.5 & 14.4 & 20.7 & 30.1 & 36.6 & 44.3 & 41.9 \\
\hline Strongly agree & 51.6 & 50.6 & 78.0 & 74.7 & 58.6 & 50.0 & 37.5 & 28.1 \\
\hline
\end{tabular}


average, the children (aged 3-6) spent $36.9 \mathrm{~h}$ a week in daycare (median value). Considering that both mothers and fathers report a median work week of $40.0 \mathrm{~h}$, this can be regarded as a relatively low figure and presumably, daycare hours for the children under 3 would be even shorter.

Against this background, it seems relevant to explore both the ways in which daycare hours are kept down and the implications of the ambition to limit hours.

The first research question concerns how longer/shorter daycare hours are related to mothers' and fathers' work hours. Latent class analysis was used to identify family patterns of work hours and daycare hours and the best fit for the data was the five-cluster model displayed in Table 2 (for model fit statistics, see Table 5, "Appendix"). As seen in the table, cluster 1 is the largest cluster with about $31 \%$ of the respondents while the other clusters are equal in size, each comprising 16-18\% of the respondents. Except for cluster 5, all clusters clearly differ in their gender composition, with fathers found mainly in clusters 1 and 4 and mothers equally divided between clusters 1, 2 and 3 .

Cluster 1 consists of families where both parents work full-time and is characterized by mixed daycare hours: two thirds of the respondents use long daycare hours, while one third report short hours. Clusters 2 and 4 are characterized by short daycare hours. Both clusters are dominated by families in which the mother works part-time; yet, about $30 \%$ of work full-time. As a contrast, clusters 3 and 5 are both dominated by long daycare hours. Cluster 3 comprises mothers who work full-time and who are either single parents or living with a partner who works full-time or more. Cluster 5 is dominated by families in which both parents work more than full-time, although in about one third of the cases one partner works normal full-time.

The cluster analysis indicates that short daycare hours are related to traditionally gendered arrangements in which mothers work part-time and fathers full-time. However, on closer inspection we find that daycare hours can be kept short also when parents work fulltime, as demonstrated in clusters 1, 2 and 4. Long daycare hours are found in families consisting of single mothers and among couples in which the father or both parents work more than full-time. All in all, the patterns suggest that female part-time is not the only way to limit daycare hours. In the next step, we will explore the idea that flexible work arrangements and sharing of care work in the family allow both parents to work full-time without prolonging daycare hours.

Table 3 displays the results from linear regressions used to examine how the probability of belonging to each cluster is related to schedule flexibility, spatial flexibility and the sharing of care work in the family. In model 1 we note that the clusters differ not only in their gender composition but also in terms of the educational level of the respondents. Parents with non-university education are commonly found in clusters 2 and 4 with short daycare hours while parents with a university degree are likely to belong to clusters 1 and 5 with mixed or long daycare hours. Finally, cluster 3 comprises mothers of all educational groups.

In model 2, we take a closer look at the arrangements of paid and unpaid work by entering variables capturing flexible work arrangements and sharing of care responsibilities. Here we find that in cluster 1, both parents have flexible schedules and fathers tend to share childcare responsibilities with the mothers. Presumably, then, taking shifts in the home could explain why a fair share of the parents in this cluster can keep daycare hours short despite working full-time. At the same time, the majority of parents in this cluster use long daycare hours, perhaps because two daytime schedules with little spatial flexibility limit the possibilities for taking shifts in the home. Cluster 2 confirms the impression that daycare hours can be kept short by other means than part-time work. As shown in model 2, mothers in this cluster do not tend to have flexible schedules, however, they have a partner with a 


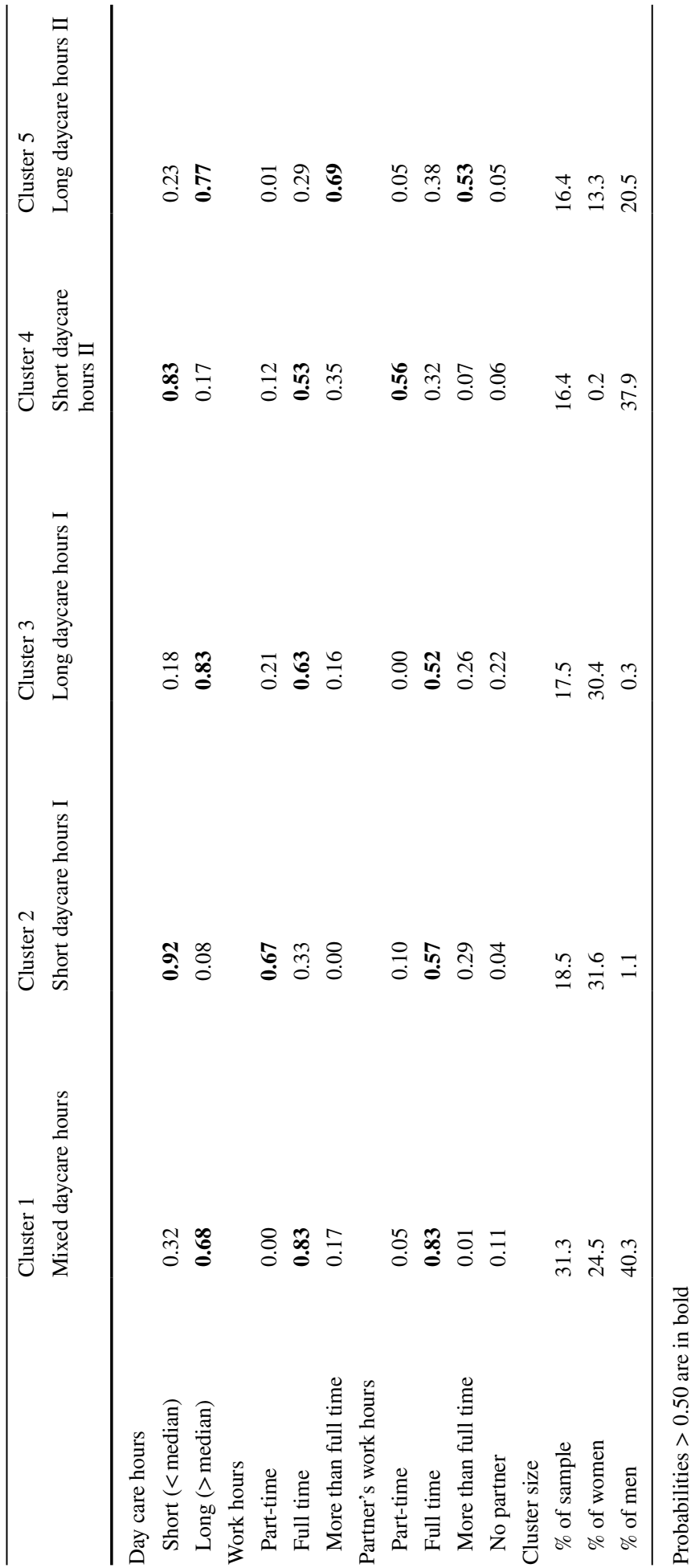




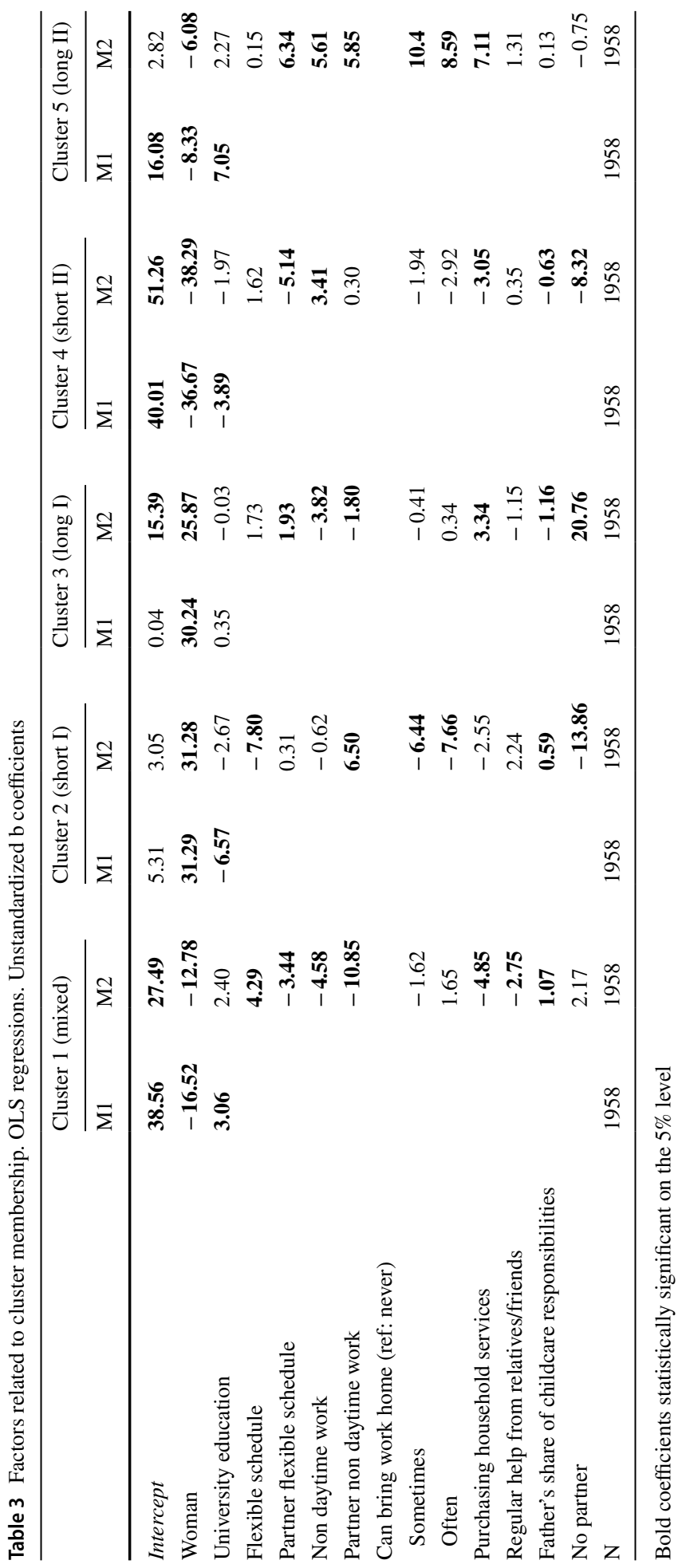


non-daytime schedule. Moreover, the fathers tend to share the responsibilities for childcare. As in the previous cluster, then, the patterns here suggest that mothers who combine fulltime work with short daycare hours - about one third of the mothers in the cluster-tend to share childcare responsibilities with their partners based on 'shift-working' arrangement. Meanwhile, cluster 4 displays a more traditionally gendered division of paid and unpaid work. For the fathers dominating this group, a partner working part-time is the main means by which daycare hours are kept down. Although the men and their partners tend to work complementary shifts, with her on daytime and him on a non-daytime schedule, parents in this cluster do not seem to alternate shifts in the home and share the responsibilities for care work. In cluster 3, the long daycare hours reflect the fact that mothers work full-time and carry the main responsibility for care work. In this cluster we find single mothers but also married/cohabiting mothers whose partners work full-time or more. Both parents work daytime and fathers do not seem to use their schedule flexibility to shorten daycare hours. In cluster 5, both parents tend to work more than full-time and commonly have non-day schedules. Despite some schedule flexibility (for one parent) and possibilities for teleworking, these families report long daycare hours. Also, we find that in both cluster 3 and 5 , daycare hours are long despite the fact that parents purchase household services. Finally, it can be noted that for all clusters, the coefficient signifying education loses statistical significance in model 2. Thus, parents with and without university education tend to have different work-family arrangements. These are based on differences in work conditions, notably access to flexible schedules, which imply different possibilities for organizing childcare.

In response to RQ 1a-b, then, we note that female part-time work remains an important tool for managing children's time in daycare. However, full-time work can be combined with short daycare hours, provided that parents have the possibility and willingness to take shifts in the home. Such arrangements seem to require the right schedule fit (daytime for one parent, non-daytime for the other) and/or flexible schedules that allow both parents to rearrange work hours so that children can be picked up from daycare in the early afternoon, have a late morning or a day off. Importantly, these arrangements also require that care responsibilities are shared more equally between the parents. Finally, long work hours for one parent or both effectively counteract the possibility to keep daycare hours down, even if parents enlist friends/relatives to help them or purchase household services on the market.

Next, we turn to the issue of daycare hours and parental stress. Table 4 displays the results from ordinary least square regressions exploring how daycare hours and ambitions to limit daycare hours are related to perceived stress among mothers and fathers, respectively. For mothers, models 1-2 show that both the ambition to limit daycare hours and long daycare hours are significantly related to higher levels of stress. The coefficient for long daycare hours becomes non-significant when controlling for job demands and job control, suggesting that the enhanced stress is attributable to high work strain. The ambition to limit daycare hours remains a source of stress when accounting for work strain and actual daycare hours; however, in model 4, the coefficient loses statistical significance. This model shows that fathers' participation in childcare is related to mothers' perception of everyday stress and the significant interaction term in model 5 further demonstrates that stress connected to mothers' ambition to limit daycare hours is significantly reduced if fathers take on more responsibility for childcare. For fathers, the patterns for fathers look quite different. As the table shows, fathers' reported ambitions to limit daycare hours are not related to their perceptions of stress and neither are the actual daycare hours of the children, either before or after controlling for education, job demands and control. Moreover, the non-significant interaction variable in model 5 shows that, even when fathers take a 


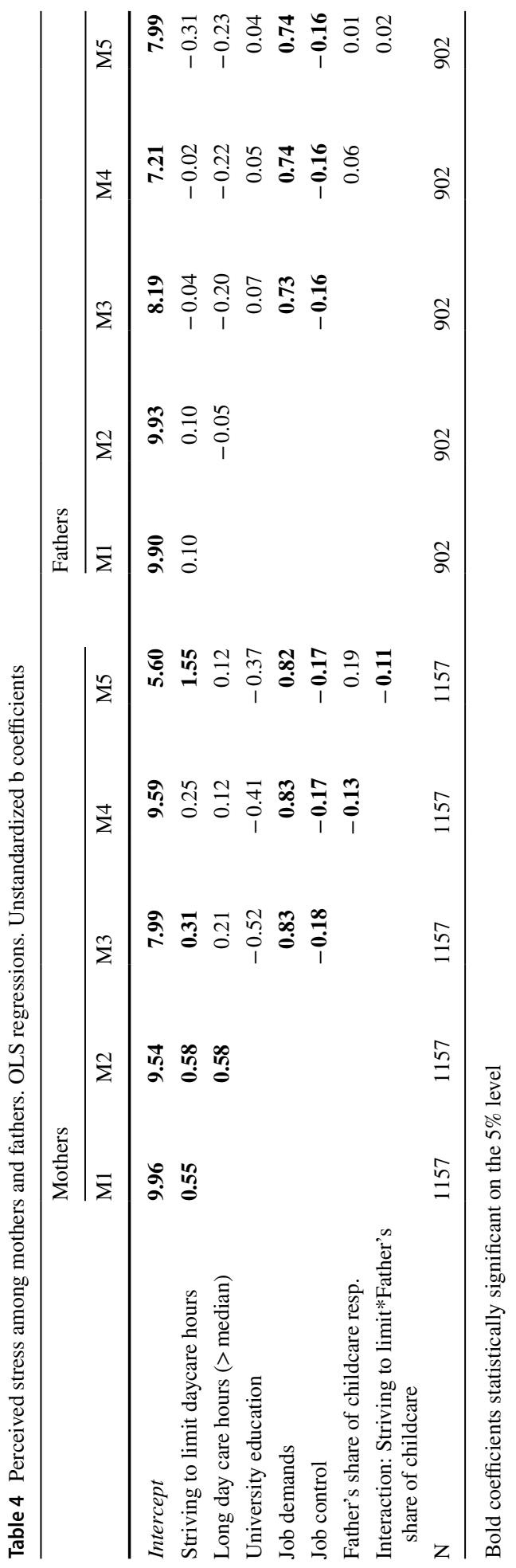


larger part of child care responsibilities, deliberations on daycare hours does not seem to translate into stress as it does for mothers.

In sum, the answer to RQ $2 a-b$ is that the desire to limit daycare hours has different consequences for mothers and fathers. For mothers but not for fathers this ambition is a source of stress. A more equal sharing of care responsibilities is a buffer that moderates women's stress, without increasing fathers' perceptions of stress. In the next section, these relationships will be further explored with qualitative data.

\section{Results: Part 2 (Qual)}

In the qualitative analysis, the importance of limiting daycare hours emerges as an overarching theme. This theme is identifiable in practically all interviews and can be regarded as a societal discourse to which the parents relate, albeit in different ways. Below, we will first report the parents' motives for limiting daycare hours, then their strategies. Themes and subthemes are presented in italics.

In the narratives, the ambition to limit daycare hours emerges as a strong guiding principle but also as an adjustable goal. As a guiding principle, this ambition is closely related to the respondents' ideals of parenthood and forms their work-family arrangements. Under this theme, two main motives can be discerned. For several respondents, the desire to create family time is a prime motive. These parents emphasize their wish to spend time with their children while they are small, create time for common activities such as family meals and bedtime stories, as well as for taking children to leisure activities. By limiting daycare hours parents also feel that they retain the main responsibility for raising and educating their children. Here, respondents emphasize that they want to be a role model for their children and transfer values, attitudes and knowledge, i.e., different forms of cultural and human capital. Says Anders, a father of three: "We want to spend time with them and follow them as they grow up. Also, you don't want them to spend more time in daycare than they do at home. You want them to be brought up by the family so to speak". Finally, parents wish to show that they are available to their children even on work days, to provide support, care and love. Under this theme, then, limiting daycare hours appears to be about doing family and displaying a responsible parenthood.

The second motive for parents striving to limit daycare hours can be summarized as coping with stress. Two aspects of stress are brought up. In particular, parents talk about the strain experienced by the children in daycare services. As mentioned, Swedish children are commonly enrolled in daycare at an early age and few if any respondents question this practice. Instead, daycare services are discussed as an integral part of good parenthood. Parents appreciate that their children can interact with their peers and develop skills they cannot acquire in the family and they are generally contented with their daycare arrangements. At the same time, several respondents feel that daycare has downsides, especially for younger children. Long hours in daycare are seen as tiring, particularly as the groups are often perceived to be too large. For parents of children with serious diseases or neuropsychiatric disabilities these aspects are particularly problematic. "Daycare does not really fit our son who has autism. Last year there were 26 children in the group, one of them with autism and others with other diagnoses", says Mikael, a carpenter who took up part-time work to tend to his son's needs. The second aspect of coping relates to the stress perceived by parents as they juggle the demands of work and family. Here, respondents emphasize that they wish to be mentally present and engage in their children's activities and problems 
without getting irritated or exhausted. If the children are picked up early from daycare this scenario is more likely to happen as both the parent and the child will be less stressed out. For Johanna, a physiotherapist with three children, this was the main reason for taking up part-time work. "It gets so stressful when you come home and often the children have other activities in the evening. I feel less stressed if I am home to organize things and prepare dinner and gather their stuff they need to take with them. It gets more peaceful."

Some gendered patterns can be discerned in the parents' reasoning on motives. Although both male and female respondents talk about limiting daycare hours as a strong guiding principle, motives differ. In particular, mothers much more emphasize the motive of coping with strain. Presumably, such differences reflect the fact that in general women have the main responsibility for the care of young children. Interestingly, men who mention stress as a motive tend to have larger care responsibilities, either because they are single fathers or because their children have special needs.

While many parents see short daycare hours as a principle guiding their work-family arrangements, others talk about it as an adjustable goal. These parents state that they have rivalling aspirations that modify their intention to keep daycare hours down. These other goals can involve maintaining a certain living standard, pursuing a career or other interests such as socializing or going to the gym. Some report that the goal of limiting hours was important when the children were very small but could be modified as they grew older. Cecilia emphasizes that she never worried about her children's time at the daycare center: "I am not this person who thinks daycare is something ugly. Our children were enlisted in daycare already when they were one year old and well, we try to pick them up by four o'clock but I have no problem with that whole thing, you know, with daycare". We tell our children that our lives require that I and daddy work, that is how we get money". Others frame their standpoint as a norm critique, arguing that the ideal of short hours can be a source a work-family conflict for mothers. However, these respondents, too, emphasize that they pay close attention to their children's wellbeing and make sure that daycare hours are reasonable. "I know many parents feel that they have to pick up their children early because everyone else does, but my daughter enjoys being at the daycare center. She is having fun there, I don't remember her ever being sad. If she would suffer from having longer days than other kids I would do something about it but I don't care about social norms, I just do what is right for my family", says Elin, a mother of five. All in all, the narratives suggest that limiting daycare hours is a societal discourse that parents must relate to, although the precise meaning of this ideal is negotiable.

Next, we turn to the issue of strategies. Just as the quantitative findings, the interviews suggest that part-time work is an important means by which families keep daycare hours down. However, although parents have a statutory right to reduce work hours, the use of part-time work is not uncomplicated. Four different themes can be discerned around the arrangement of work hours and care responsibilities: part-time as a mother's choice, parttime as a common strategy, full-time as a default option and, finally, accounts of alternative arrangements.

A prominent theme is that of part-time as the mother's choice. Clearly, mothers who work part time claim they chose it to keep daycare hours down. This account is echoed by fathers who emphasize that they did not put any pressure on their partner. Some say that they too would have been willing to work part-time but that the woman was granted a first choice. However, the possibility for the father to reduce hours does not seem to have been much discussed. Says Anna: "It was just natural that I would do it. I think I just told him that this is what I want and that is how it turned out." In effect, then, the right to part-time is handled as the woman's right although it is talked about in gender-neutral terms. Though 
the mothers' part-time work also implies taking on the main responsibility for household chores, this is not perceived as unfair. Respondents in this group emphasize the logic of complementary roles, underlining that the fathers focus more on paid work. At the same time, they relate to norms of gender equality by underlining that fathers help out with the children. Says Karin, who has worked part-time to care for seven children: "He understands that I am working too and does his share. Even if I do most [of the housework] I get the help I want."

Though the previous theme dominates in the families using part-time work, some respondents discuss part-time as a common strategy. In these families, both partners are intent on keeping daycare hours short but also want to share care responsibilities equally and have the same possibility to pursue their careers. For Cecilia and her partner, both in research careers, this was an important principle. "We divided the parental leave equally, he took six months and I took 5.5, and then we both worked part-time for quite a long time." In other cases, part-time as a common strategy is discussed as an unfulfilled wish. Some mothers report that they took up part-time work hoping that their partner would, too. As this did not happen they feel that the division of housework has become too unbalanced. Johanna has tried to convince her husband to use his parental leave days and the right to work hour reductions: "I think he should work part-time so we can share [housework]. So that it is not just my responsibility to make sure that the children can have dinner before their activities and things like that. But it's an ongoing discussion (laughs)". In these discussions, Johanna finds that her partner does not worry much about daycare hours. Jenny a medical secretary with two children makes the same reflection. "I don't think he understands why I reduced my work hours. He says we have daycare and that's great. And I try to explain that it is really hard with these long days in daycare and that they are never at home. These long daycare hours have always given me a bad conscience", says Jenny who feels that she does "everything" around the house. Relating to the lack of common strategies, Gustav says he saw no reason why his wife should work part-time and argues that men tend to get blamed for inequalities resulting from women's work adaption. "It is not just her choice, there is also a social pressure [on mothers]. But it was a bit stressful for her. She had a bad conscience because the children had long days at the daycare center. We think differently about that. I don't think [limiting daycare hours] is as important as she does."

Interestingly, also parents working full-time relate to the possibility of part-time work by motivating why they do not use the right to work reductions. Here, many male respondents present their full-time work as a default option, emphasizing that in practice part-time is not possible. Income is quoted as a main reason. For this reason, single parents do not see part-time work as an option. Also, several fathers argue that because they have higher wages than their partner they provide economically for their families and have little possibility to work part-time. However, obstacles can be found also in the norms and demands of the workplaces, particularly in jobs dominated by men. Niklas, who works in border control found that his colleagues complained about his request for a more family-friendly work schedule. "There is this culture, particularly among the older [colleagues]. There is still a strong notion that the woman should take most of the responsibilities for the children while you should focus only on your work." In many families, the mother's part-time work is the main strategy by which daycare hours are kept down. Nevertheless, fathers emphasize that they, too, have adapted their work in order to take part in childcare, for example by limiting overtime hours or business travels. Says Anders, a father of three: "I used to travel more and very often stay overnight and of course that put more of a burden on [my partner]. Now I do less travelling and I work from home each Friday so that I can leave and 
pick up the children from daycare." However, it should be noted that also some mothers state that their work situation makes it difficult to utilize the right to part-time work. Says Sara, a medical doctor and a single mother with two children: "In my profession [parttime] can actually be more stressful than full-time. It is difficult to get away from work." Similarly, Julia feels that her managerial work would be more stressful if she reduced work hours "You still have to do a hundred percent."

Rather than highlighting the obstacles to part-time work, other respondents stress that their full-time jobs offer alternative arrangements which enable them to keep daycare hours reasonably short. Here, two subthemes can be discerned. First, the parents talk about their arrangements as based on time-space flexibility, emphasizing how they are able to rearrange work hours rather than reducing them. Due to their possibilities for flexible scheduling, often in combination with a spatial flexibility that allows them to do part of their work from home, these parents can pick up their children comparatively early, despite the fact that both the mother and the father have full-time jobs. Complementary shifts - with one parent on daytime and the other on a non-standard schedule_-also modify the problems of combining fulltime work with short daycare hours. "We both have demanding jobs but also understanding employers so we manage our own time. You don't have to ask for permission, nobody wonders where you are if you leave an hour early", says Magnus, an engineer with three children. Echoes Tomas: "We are fortunate to have very flexible jobs. That makes things a lot easier."

The second theme features a contract of sharing the responsibilities for care work and household chores. In these families, the parents talk about a contract, in the sense of a negotiated agreement. The contract has a stated objective of limiting daycare hours while simultaneously allowing both parents to engage in work and career (as well as personal interests). Endorsed by both parents (though not necessarily in writing), this contract includes detailed schedules by which partners rotate the responsibility of taking children to/from daycare as well as other tasks related to care and housework. The contact may be labelled a gender equality contract and many parents talk about it not just as a practical arrangement but as an expression of their ideals of equal roles. Every other day, Fredrik and his partner rotate between a morning and an evening shift and the person in charge takes care of all childcare and household chores. "We have shared everything equally since the day our son was born-parental leaves, sick days, school meetings and the leaving and picking up from daycare. Without this strict principle of fairness you end up discussing whose job is more important, but we don't let economic aspects decide." Particularly when combined with possibilities for time-space flexibility, these contracts allow the parents arrange both paid and unpaid work in rotating shifts and thereby keep children's daycare hours short. However, such arrangements also allow parents to adjust the goal of limiting daycare hours by emphasizing other goals, notably that of the dualearner/dual-carer family. For Fredrik and his wife, short daycare hours were less important than the gender equality contract which allowed her to pursue her career and him to have a closer relationship with his son. "Many parents try to leave the children at eight and pick them up by three and the result is often a more gendered division of time."

The qualitative analysis, focusing parents' talk about daycare (RQ 3) and the issue of stress (RQ 4), complements and deepens the insights obtained from the quantitative analysis. Three findings stand out. First, the ambition to limit daycare hours appears as a stressful dilemma for mothers. Second, though part-time work is statutory right for Swedish parents it does not appear either as a straightforward solution to these dilemmas, or as the only solution. Instead, the quantitative and qualitative data both suggest that gender equality contracts, based on an organized and sequential sharing of care work, allow parents to remain in full-time jobs and either keep daycare hours short or modifying this goal. Both mechanisms can explain why such arrangements tend to modify mother's stress. 


\section{Discussion}

Based on the case of Sweden, the study was designed to explore the role of daycare in the transition from a one-and-a-half-earner society to a dual-earner society with equal roles and responsibilities for men and women. The overarching question-little addressed in previous research-is whether daycare services can alleviate work-family tensions and allow for two full-time careers or if perceptions of 'care gaps' will constrain and complicate mothers' work involvement. Combining survey and interview data, we analyzed how parents' deliberations on daycare usage - specifically, children's daycare hours-relate to work-family arrangements and parental stress.

A prominent message from both datasets is the imperative need for parents to limit the time their children spend in daycare. Limiting daycare hours emerges as a societal discourse but with different implications for different groups of parents.

In particular, the ambition to limit daycare hours appears as a stressful dilemma for mothers, reflecting the fact that mothers are assigned with the prime responsibility for the care and well-being of children, symbolically and practically. In this situation, limiting daycare hours is a way to handle work-family conflict and stress. At the same time, however, the desire to limit daycare hours is also a source of stress. These relationships, apparent in both the quantitative and the qualitative data, were not found for fathers.

Part-time work is an important tool for limiting daycare hours and a statutory right for Swedish parents. However, parents navigate in a context of competing logics that complicate the use of part-time. With persistent gender differences in wages, positions and work demands, a logic of within-household specialization can still be evoked. At the same time, the respondents strongly embrace the ideal of the dual-earner/dual-carer family. In this situation, both the quantitative and the qualitative analyses point to the importance of family contracts, based on equal sharing. The findings show that if childcare responsibilities are shared both parents can work full-time daycare hours and still keep daycare hours short. Also, fathers' participation in childcare is crucially related to mothers' stress stemming from the ambition to limit daycare hours. The qualitative analysis suggests several mechanisms for explaining these findings. To some extent, parents may keep daycare hours down by shift-working arrangements in the home. However, these contracts based on ideals of equal roles in paid work and family also allow parents to modify the ambition to limit daycare hours.

In practice, then, the ambition to limit daycare hours is translated into a range of different work-family arrangements and clearly, the possibilities differ between different groups. The contracts of equal sharing discussed above are more common among parents with a university education, who more often have access to flexible schedules. Meanwhile, arrangements based on maternal part-time work are more common among parents with lower education. For single parents who lack a partner with whom to share daily responsibilities and who often cannot afford to work part-time it is difficult to keep daycare hours short. Thus, while provision of daycare is crucial for single parents, the usage of daycare is also a source of daily stress. Finally, the interviews suggest that further pressures will arise if cutbacks in welfare state spending affect the quality of daycare services.

Several limitations should be mentioned. Clearly, cross-sectional survey data does not allow for inferences about causal relationships and the response rate calls for some caution in the interpretation of the results. In particular, results may not reflect the situation of marginalized groups as low-educated parents were underrepresented among the respondents. Therefore, and considering that in practice, family policy rights and benefits require a stable labour market attachment, the work-family dilemmas of these groups call for more in-depth 
studies. Qualitative interview data based on a strategic sampling of survey respondents was used to further explore and complement the survey findings. A drawback of this sequential design was however that the interviews were carried out retrospectively. Finally, it is not obvious that quantitative and qualitative data will provide a mutual validation (Erzberger and Kelle 2003). A prime motive for using mixed methods is to improve the quality of inferences, but we do not argue that a convergence of findings will automatically strengthen validity. Instead, the analysis is based on a complementary model in which the two types of data supplement each other to produce a fuller picture of the phenomenon (ibid 484).

In essence, the article puts the spotlight on the 'de-familializing' capacity of daycare, but beyond the issue of female labour force participation. The findings point to an interplay between family care and daycare which reflects the family policy context. Swedish family policies provide parents with a right to work, but also a right to care and previous research shows that women display strong orientations towards both family and career and that a simultaneous engagement in both spheres entails both conflict and well-being (Grönlund and Öun 2010, 2018). Thus, ambitions to limit daycare hours should not be automatically equated with outdated motherhood ideals and, as demonstrated, it can entail doing gender as well as 'doing gender equality'.

The questions posed in this article has a relevance far beyond the Swedish context. Across Europe, women's employment still falls behind that of men and many women work on a part-time basis (Eurostat 2019a) and to facilitate the transition from a 1,5-earner to a dual-earner society, many countries develop new policies. However, the impact of family policies on work-family dilemmas has not been sufficiently theorized (cf. Grönlund and Öun 2010). Policies can be regarded as institutional scripts and these scripts, that is, the stories policies tell about themselves - in this case, as enabling a dual-earner, gender equal family — can raise expectations that in many ways will collide with realities. Here, daycare services play a central role and in future research, the use and usability of daycare needs to be studied in different policy contexts.

Acknowledgements Open access funding provided by Umeå University. The authors wish to thank PhD Sara Kalucza and PhD Cristine Isaksson, both Umeå university, for planning and conducting the interviews. For financial support, the authors gratefully acknowledge the Swedish Research Council for Health, Working Life and Welfare (FORTE), Grant Number 2013-0342, and the Swedish Social Insurance Agency (Försäkringskassan), Grant Number 052665-2017.

Open Access This article is licensed under a Creative Commons Attribution 4.0 International License, which permits use, sharing, adaptation, distribution and reproduction in any medium or format, as long as you give appropriate credit to the original author(s) and the source, provide a link to the Creative Commons licence, and indicate if changes were made. The images or other third party material in this article are included in the article's Creative Commons licence, unless indicated otherwise in a credit line to the material. If material is not included in the article's Creative Commons licence and your intended use is not permitted by statutory regulation or exceeds the permitted use, you will need to obtain permission directly from the copyright holder. To view a copy of this licence, visit http://creativecommons.org/licenses/by/4.0/.

\section{Appendix}

Each model includes the three manifest nominal-level indicators as well as the manifest covariate gender. In Table 5, the $\mathrm{L}^{2}$ value in the baseline model (1) indicates the maximum association between the manifest variables that can be explained by any latent class model. Judging on the BIC statistic (the lower the value, the better the model), this model should be rejected in favour of a more complex model. By relying only on the BIC statistic, it is 
Table 5 Model-fit statistics for five latent class models

\begin{tabular}{lrrrcc}
\hline & $\mathrm{L}^{2}$ & $\mathrm{BIC}\left(\mathrm{L}^{2}\right)$ & $\mathrm{df}$ & $\mathrm{L}^{2}$ reduction $(\%)$ & $p$ value \\
\hline 1-Cluster & 797.07 & 492.05 & 40 & 0.00 & 0.000 \\
2-Cluster & 403.41 & 159.39 & 32 & 49.39 & 0.000 \\
3-Cluster & 112.54 & -70.48 & 24 & 85.88 & 0.000 \\
4-Cluster & 41.84 & -80.17 & 16 & 94.45 & 0.000 \\
5-Cluster & 11.84 & -49.17 & 8 & 98.51 & 0.160 \\
\hline
\end{tabular}

suggested that the 4-cluster model should be chosen. However, the significant $p$ value indicates that the 5-cluster model is a better cluster solution. This decision is strengthened by additional bootstrapping analysis (bootstrapped $\mathrm{L}^{2}$ ) showing that the five-cluster solution is significantly better that the four-cluster solution (not shown). The $\mathrm{L}^{2}$ value is reduced by as much as $98.5 \%$ and the bivariate residuals between the manifest variables are nonsignificant (not shown in table).

\section{References}

Ahlberg, J., Roman, C., \& Duncan, S. (2008). Actualizing the "Democratic Family"? Swedish policy rhetoric versus family practices. Social Politics, 15(1), 79-100. https://doi.org/10.1093/sp/jxn003.

Allen, T. D., Johnson, R. C., Kiburz, K. M., \& Shockley, K. M. (2013). Work-family conflict and flexible work arrangements: Deconstructing flexibility. Personnel psychology, 66(2), 345-376. https://doi. org/10.1111/peps.12012.

Angelov, N., Johansson, P. \& Lindahl, E. (2013). Gender differences in sickness absence and the gender division of family responsibilities. IZA discussion paper no. 7379. Available at https://ssrn.com/abstr act $=2263655$. Accessed 17 May 2020.

Angelov, N., Johansson, P., \& Lindahl, E. (2016). Parenthood and the gender gap in pay. Journal of Labor Economics, 34(3), 545-579. https://doi.org/10.1086/684851.

Bambra, C. (2007). Going beyond the three worlds of welfare capitalism: Regime theory and public health research. Journal of Epidemiology \& Community Health, 61(12), 1098-1102. https://doi.org/10.1136/ jech.2007.064295.

Bettio, F., \& Plantenga, J. (2004). Comparing care regimes in Europe. Feminist Economics, 10(1), 85-113. https://doi.org/10.1080/1354570042000198245.

Björklund, A., Fredriksson, P., Gustafsson, J.-E., \& Öckert, B. (2010). Den svenska utbildningspolitikens arbetsmarknadseffekter: vad säger forskningen? IFAU rapport 2010:13. Uppsala: IFAU.

Boye, K. (2014). Hushållsarbetets tid och fördelning. In K. Boye \& M. Nermo (Eds.), Lönsamt arbete familjeansvarets fördelning och konsekvenser SOU 2014:28 (pp. 95-129). Stockholm: Fritzes.

Boye, K. (2019). Care more, earn less? The association between taking paid leave to care for sick children and wages among Swedish parents. Work, Employment and Society. https://doi.org/10.1177/09500 17019868138 .

Boye, K., \& Evertsson, M. (2014). Vem gör vad när? Kvinnors och mäns tid i betalt och obetalt arbete. In M. Evertsson \& C. Magnusson (Eds.), Ojämlikhetens dimensioner (pp. 158-184). Stockholm: Liber.

Boye, K., Halldén, K., \& Magnusson, M. (2017). Stagnation only on the surface? The implications of skill and family responsibilities for the gender wage gap in Sweden, 1974-2010. British Journal of Sociology, 68(4), 595-619. https://doi.org/10.1111/1468-4446.12252.

Braun, V., \& Clarke, V. (2013). Successful qualitative research: A practical guide for beginners. Thousand Oaks: Sage.

Bygren, M., \& Duvander, A. Z. (2006). Parents' workplace situation and fathers' parental leave use. Journal of Marriage and Family, 68(2), 363-372. https://doi.org/10.1111/j.1741-3737.2006.00258.x.

Bygren, M., Erlandsson, A., \& Gähler, M. (2017). Do employers prefer fathers? Evidence from a field experiment testing the gender by parenthood interaction effect on callbacks to job applications. European Sociological Review, 33(3), 337-348. https://doi.org/10.1093/esr/jcx051. 
Bygren, M., \& Gähler, M. (2012). Family formation and men's and women's attainment of workplace authority. Social Forces, 90(3), 795-816. https://doi.org/10.1093/sf/sor008.

Byron, K. (2005). A meta-analytic review of work-family conflict and its antecedents. Journal of Vocational Behavior, 67(2), 169-198. https://doi.org/10.1016/j.jvb.2004.08.009.

Creswell, J. W., Plano Clark, V. L., Gutmann, M. L., \& Hanson, W. E. (2003). Advanced mixed methods research designs. In A. Tashakkori \& C. Teddlie (Eds.), Handbook of mixed methods in social \& behavioral research (pp. 209-240). Thousand Oaks, California: Sage.

Daly, M. (2011). What adult worker model? A critical look at recent social policy reform in Europe from a gender and family perspective. Social Politics: International Studies in Gender, State \& Society, 18(1), 1-23. https://doi.org/10.1093/sp/jxr002.

Edlund, J., \& Öun, I. (2016). Who should work and who should care? Attitudes towards the desirable division of labour between mothers and fathers in five European countries. Acta Sociologica, 59(2), 151-169. https://doi.org/10.1177/0001699316631024.

EIGE. (2019). Gender Equality Index 2019. European Institute for Gender Equality (EIGE). Retrieved November 25, 2019, from https://eige.europa.eu/gender-equality-index/2019.

Elvin-Nowak, Y. (1999). The meaning of guilt: A phenomenological description of employed mothers' experiences of guilt. Scandinavian Journal of Psychology, 40(1), 73-83. https://doi. org/10.1111/1467-9450.00100.

Erzberger, E., \& Kelle, U. (2003). Making inferences in mixed methods: The rules of integration. In A. Tashakkori \& C. Teddlie (Eds.), Handbook of mixed methods in social \& behavioral research. Thousand Oaks: Sage.

Eurostat. (2019a). Statistics explained: eEmployment statistics. Retrieved November 25, 2019, from https://ec.europa.eu/eurostat/statistics-explained/index.php/Employment_statistics.

Eurostat. (2019b). Statistics explained: Fertility statistics. Retrieved November 25, 2019, from https:// ec.europa.eu/eurostat/statistics-explained/index.php/Fertility_statistics.

Gornick, J. C., \& Meyers, M. K. (2008). Creating gender egalitarian societies: An agenda for reform. Politics \& Society, 36(3), 313-349. https://doi.org/10.1177/0032329208320562.

Grönlund, A., Halldén, K., \& Magnusson, C. (2017). A Scandinavian success story?: Women's labour market outcomes in Denmark, Finland, Norway and Sweden. Acta Sociologica, 60(2), 97-119. https://doi.org/10.1177/0001699316660595.

Grönlund, A., \& Kaufman, G. (2019). Displaying parenthood, (un)doing gender: Parental leave, daycare, and working time adjustments in Sweden and the UK. Families, Relationships and Societies. https ://doi.org/10.1332/204674319X15683716957916.

Grönlund, A., \& Öun, I. (2010). Rethinking work-family conflict: Dual-earner policies, role conflict and role expansion in Western Europe. Journal of European Social Policy, 20(3), 179-195. https://doi. org/10.1177/0958928710364431.

Grönlund, A., \& Öun, I. (2018). In search of family-friendly careers? Professional strategies, work conditions and gender differences in work-family conflict. Community, Work \& Family, 21(1), 87-105. https://doi.org/10.1080/13668803.2017.1375460.

Grunow, D., \& Evertsson, M. (Eds.). (2016). Couples' transitions to parenthood: Analysing gender and work in Europe. Cheltenham: Edward Elgar Publishing.

Hagenaars, J. A., \& McCutcheon, A. L. (2002). Applied latent class analysis. Cambridge: Cambridge University Press.

Hays, S. (1998). The cultural contradictions of motherhood. London: Yale University Press.

Hobson, B., Fahlén, S., \& Takács, J. (2011). Agency and capabilities to achieve a work-life balance: A comparison of Sweden and Hungary. Social Politics, 18(2), 168-198. https://doi.org/10.1093/sp/ jxr007.

Karasek, R. A., \& Theorell, T. (1990). Healthy work. Stress, productivity and the reconstruction of working life. New York: Basic Books.

Korpi, W. (2000). Faces of inequality: Gender, class and patterns of inequalities in different types of welfare states. Social Politics: International Studies in Gender, State \& Society, 7(2), 127-191. https://doi.org/10.1093/sp/7.2.127.

Korpi, W., Ferrarini, T., \& Englund, S. (2013). Women's opportunities under different family policy constellations: Gender, class, and inequality tradeoffs in western countries re-examined. Social Politics: International Studies in Gender, State \& Society, 20(1), 1-40. https://doi.org/10.1093/sp/jxs028.

Lareau, A. (2003). Unequal childhoods: Class, race, and family life. Berkeley, CA: University of California Press.

Lister, R. (2003). Citizenship: Feminist perspectives. London: Palgrave. 
Lohmann, H., \& Zagel, H. (2016). Family policy in comparative perspective: The concepts and measurement of familization and defamilization. Journal of European Social Policy, 26(1), 48-65. https:// doi.org/10.1177/0958928715621712.

Magnusson, C., \& Nermo, M. (2017). Gender, parenthood and wage differences: The importance of time-consuming job characteristics. Social Indicators Research, 131(2), 797-816. https://doi. org/10.1007/s11205-016-1271-z.

Mandel, H. (2012). Winners and losers: The consequences of welfare state policies for gender wage inequality. European Sociological Review, 28(2), 241-262. https://doi.org/10.1093/esr/jcq061.

Mandel, H., \& Semyonov, M. (2006). A welfare state paradox: State interventions and women's employment opportunities in 22 countries. American Journal of Sociology, 111(6), 1910-1949. https://doi. org/10.1086/499912.

McCutcheon, A. L. (1987). Latent class analysis (Sage University paper series on quantitative applications in the social sciences, no. 07-064). Newbury Park, CA: Sage.

Michel, J. S., Kotrba, L. M., Mitchelson, J. K., Clark, M. A., \& Baltes, B. B. (2011). Antecedents of workfamily conflict: A meta-analytic review. Journal of Organizational Behavior, 32(5), 689-725. https:// doi.org/10.1002/job.695.

Miles, M. B., Huberman, A. M., \& Saldaña, J. (2014). Qualitative data analysis: A methods sourcebook. Source book of new methods (3rd ed.). Baverly Hills: SAGE Publications Inc.

Onwuegbuzie, A. J., \& Teddlie, C. (2003). A framework for analysing data in mixed methods research. In A. Tashakkori \& C. Teddlie (Eds.), Handbook of mixed methods in social \& behavioral research (pp. 351-384). Thousand Oaks, CA: Sage.

Pitt-Catsouphes, M., Kossek, E. E., \& Sweet, S. (Eds.). (2006). The work and family handbook: Multi-disciplinary perspectives and approaches. London: Lawrence Erlbaum Associates.

Saxonberg, S. (2013). From defamilialization to degenderization: Toward a new welfare typology. Social Policy and Administration, 47(1), 26-49. https://doi.org/10.1111/j.1467-9515.2012.00836.x.

Statistics Sweden. (2017). Arbetskraftsundersökningarna (AKU). (Labour force surveys). Retrieved December, 2017, from https:/www.scb.se/en/finding-statistics/statistics-by-subject-area/labour-market/labou r-force-surveys/labour-force-surveys-lfs/.

Tashakkori, A., \& Teddlie, C. (2003). Handbook of mixed methods in social \& behavioral research. Thousand Oaks, CA: Sage.

Union, E. (2018). Changes in child and family policies in the EU28 in 2017 European platform for investing in children: Annual thematic report. Luxembourg: Publications Office of the European Union.

van der Doef, M., \& Maes, S. (1999). The job demand-control(-support) model and psychological wellbeing: A review of 20 years of empirical research. Work and Stress, 13(2), 87-114. https://doi. org/10.1080/026783799296084.

Publisher's Note Springer Nature remains neutral with regard to jurisdictional claims in published maps and institutional affiliations. 